\title{
An Analytical Study of Working Capital Management of Selected Cement Companies in India
}

\author{
Ahmed Mahdi Abdulkareem ${ }^{1}$, Alok Kumar Chakrawal ${ }^{2}$ \\ Email: aamahdi@sauuni.ac.in
}

${ }^{1} \mathrm{Ph} . \mathrm{D}$. Research Scholar, Department of Commerce and Business Administration, Saurashtra University, Rajkot, India

${ }^{2}$ Professor, Department of Commerce and Business Administration, Saurashtra University, Rajkot, Gujarat - 360005, India

\begin{abstract}
This article is to analyze and evaluate working capital management of selected cement companies. The main purpose of this study is to find out the liquidity position of selected cement companies in India, five companies were selection. The duration of study is five years start from 2015-16 to 2019-20. Two ratios were used for the analysis of data: current ratio quick ratio. To test hypothesis ANOVA was used. The major findings of the study indicate that there are significance difference in the quick ratio and current ratio of selected cement companies. Based on the data analysis, there is a mixed trend in the current ratio during the year 2015-16 to 2019-20. The analysis also shows the ups and down in the quick ratio of the selected cements companies during the period of 5 year. It indicates that there is mixed trend in quick ratio during the year 2015-16 to 2019-20. Removing short-term debt from balance sheet allow companies to have better quick and current ratios and allow to save some of liquidity in the near term and put in to better use. Companies are suggested to adopt more aggressiveness in maintaining their current rasio.
\end{abstract}

Keywords: Working Capital, Liquidity, Current Ratio, Quick Ratio, Management

\section{Introduction}

Work in Progress (Working Capital) is the lifeblood of any corporate enterprise. Without sufficient operating cash, a business cannot make significant development. Inadequate working capital results in a scarcity of inputs, whilst an excess of working capital results in an increase in costs. Consequently, the amount of working capital available in any organization should be neither more nor less than what is really needed. The working capital of a company serves the same function as the heart does in the human body in terms of generating revenue. Working capital funds are created and circulated throughout a company in the same way as blood circulates in the heart (Abdulkareem, 2020). This is due to the fact that working capital is sometimes referred to as circulating capital. Working capital may also play a technical role in the pursuit of the highest possible rate of return on capital invested, provided that it maintains pace with the scientific and technological advancements occurring in the sector to which it is applied. A company may be able to operate without producing profits, but it will not be able to continue without liquidity (Abdulkareem \& Meghanathi, 2020).

The role of a working capital management organization is analogous to the function of the heart in the human body in many ways. Additionally, it is a critical role of financial administration. Financial managers must decide the appropriate amount of working capital funds to maintain

Copyright (O) 2021, Journal of Asian Multicultural Research for Economy and Management Study, Under the license CC BY-SA 4.0 
a reasonable level of liquidity, as well as the optimal balance of current assets and liabilities. Moreover, he must guarantee that the right sources of cash are utilized to finance working capital, and he must ensure that the company's short-term obligations are satisfied on time. Working capital refers to the short-term finances necessary for funding operations for a period of one year or less in duration. The words of Ralph Kennedy and Stewart Mac Muller sum up the situation "Lack of sufficient operating capital is the primary reason for a company's inability to succeed. Generally speaking, working capital is that portion of a company's assets that is used in, or is related to, current operations. It is represented at any given time by the operating cycle of items such as accounts receivable, inventories of raw materials, notes or bills receivables, and cash on hand.

In contrast to the fixed capital, which is invested in a variety of fixed assets, the working capital is invested in current assets. "Cash, short-term investments in marketable securities, accounts receivable, and different forms of inventory are examples of working capital assets." In the working capital, the most important quality of assets is! The fact that they are liquid, meaning that they may be turned into cash within a fiscal year or less, places them in this category. In order for a company's operations to function properly, it is necessary to establish a suitable connection between fixed capital and current capital. Working capital is required by any commercial firm in order to pay off its short-term commitments. A further reason why every company need working capital is because its production, sales, cash payment, and realization do not occur simultaneously and in synchronization with one another. The conversion of raw materials into completed items, the selling of finished goods, and the realization of sale earnings all need a certain amount of time to complete. As a result, finances are necessary to support these types of operations inside the company.

Working capital is the term used to describe this resource. A company's working capital should be sufficient to meet the demands of its business operations. Amounts of money that contribute to the cost of capital but do not contribute to the profits. Therefore, it may result in the accumulation of large inventories, which can lead to mismanagement, waste, and theft, among other things; an excessively liberal credit policy and slack credit collection, which can lead to a higher incidence of bad debts; a speculative tendency to push sales; and managerial complacency, which can lead to inefficiency in management, wasteful expenditure, and fund diversion.

\section{Literature Review}

According to Arunkumar \& Ramanan (2013), the association between inventory days, debtor's days, creditor's days, current ratio, ratio of current obligation to total assets, financial assets to total assets, assets turnover ratio, and size with return on capital employed is investigated. The results of this study's correlation analysis reveal that the profitability of the company is significantly influenced by variables pertaining to assets. In addition, a positive relationship between profitability and debtor's days and inventory days was discovered, and a sensitivity analysis was performed to determine the coverage of return on assets was found.

The authors, Oladipupo \& Okafor (2013), addressed some research on the impact of a firm's working capital management technique on the profitability and dividend pay-out ratio for chosen firms. There is a particular emphasis in this research on the impacts of working capital management, which is taken into account throughout the trade cycle, and features of working capital management on profitability and dividend pay-out ratio. At the 5 percent level of confidence level, the findings of this research indicate that the influence of working capital management on business profitability seems to be statistically non-significant. The most significant finding in this research was that the dividend pay-out ratio was favorably impacted 
by profitability and cash conversion cycle, but that the growth rate of profits was negatively influenced.

Kieschnick et al (2013), colleagues published the first empirical research of the link between corporate working capital management and shareholders' wealth in the form of a paper. The researchers discovered evidence that the incremental dollar invested in net working capital is not worth as much as the incremental dollar held in cash for the average firm, and that the valuation of the incremental dollar invested in net operating working capital has a significant impact on future sales expectations. The time period covered by this study was 1990 to 2006. The value of an incremental dollar is comprehensive in credit creation and has a higher impact on the wealth of stockholders than a single dollar.

Hoque et al., (2015) believed that it was necessary to examine the relationship between profitability and working capital management, which they did. Working capital ratio and profitability ratio are employed for this purpose, and a correlation matrix has been created to demonstrate the relationship between two variables, with regression analysis being performed to determine the impact position. And the most noteworthy conclusion of this research is that there is a considerably positive connection between profitability and working capital qualities, as well as that the influence of day sales outstanding on profitability ratio is adversely impacted for the study period under consideration.

Working capital management is the primary focus of Paul \& Mitra (2018)'s study, which indicates a company's capacity to cover day-to-day operational expenditures as well as an indication of a company's short-term financial health, according to the researchers. Firms may plan optimal usage of the working capital component in order to achieve a balance between liquidity and profitability. In this study, an empirical model should be utilized to demonstrate a link between working capital management and profitability of the steel sector in India. Panel data regression should be employed to conduct the research.

Rajavathana Ganesamoorthy \& Rajavathana(2013), in their study the analysis is based on the Indian selected automobile companies. In this study two major companies that are Tata Motors limited and Mahindra and Mahindra selected for the analysis purpose. In this study ratio and simple percentage, which are two instruments used for finding and components of working capital should be used. Finding of the company was both companies shows efficient receivable and payable management and also found that negative cash conversion cycle during the study period for the both companies. For this study conclusion was both the companies efficiently managed their working capital components. The present work of the article has its own objectives. The work has been undertaken keeping in view certain objectives. The researcher has applied all sincere efforts to satisfy the broader objective listed below; (1) To study the liquidity position of selected cement companies; (2) To analyze and evaluate working capital management of selected cement companies.

\section{Methods}

Data collection is very important task for the researcher. There are two types of data; (1) Primary data; (2) Secondary data. The research was conducted using secondary data. The information was gathered from annual reports of selected firms that were released in the years 2015-16 to 2019-20. Other information about the chosen firms is gathered from their official websites, internet sources, books and journals, newspapers, and other media sources, among others. 


\section{Results nd Discussion}

\section{Data Analysis and Interpretation}

The data acquired has been properly sorted and collated under different categories in accordance with the study's needs, and analytical methods like as ratios, charts, and ANOVA single factor have been utilized for objective analysis and the development of significant conclusions, among other things. The current and quick ratios were utilized by the researcher to examine the performance of working capital in a sample of cement businesses.

\section{Current Ratio:}

Formula:

\section{Current ratio $=\underline{\text { Current assets }}$}

\section{Current liabilities}

The link between current assets and current liabilities is expressed by the current ratio. Its purpose is to assess the short-term financial strength of a company. The current ratio is the sum of current assets divided by current liabilities for a certain time period in a given timeframe. This ratio measures the relationship between a company's current assets and its current liabilities. In most cases, they are assets that are cash or that will be converted into cash in a year or less, as well as obligations that will be paid in a year or less, respectively. Using the current ratio, investors may get an understanding of a company's capacity to cover its shortterm debt with its current assets as well as compare it to its rivals and peers on an apples-toapples basis. Another flaw with current ratio is that it is difficult to compare across industries, that particular assets and liabilities balances are overgeneralized, and that trending information is not provided.

Table 1. Current ratio of selected cement companies

\begin{tabular}{|c|c|c|c|c|c|}
\hline Year & Ultratech & Ambuja & ACC & Shree & Dalmia \\
\hline $2015-2016$ & 0.63 & 1.24 & 0.83 & 1.39 & 0.90 \\
\hline $2016-2017$ & 0.76 & 1.35 & 1.31 & 1.22 & 0.83 \\
\hline $2017-2018$ & 0.59 & 1.60 & 1.53 & 1.12 & 0.76 \\
\hline $2018-2019$ & 0.61 & 1.72 & 1.71 & 1.50 & 0.70 \\
\hline $2019-2020$ & 0.58 & 1.57 & 1.97 & 1.08 & 0.64 \\
\hline MAX & 0.76 & 1.72 & 1.97 & 1.5 & 0.9 \\
\hline MIN & 0.59 & 1.24 & 0.83 & 1.08 & 0.64 \\
\hline AVERAGE & 0.634 & 1.496 & 1.47 & 1.262 & 0.766 \\
\hline
\end{tabular}

Source:

(https://www.google.com/URL?www.moneycontrol.com\%2F\&usg=AOvVaw2xmi4F6cHBL _upj3X) 


\section{Chart-1 Current ratio}

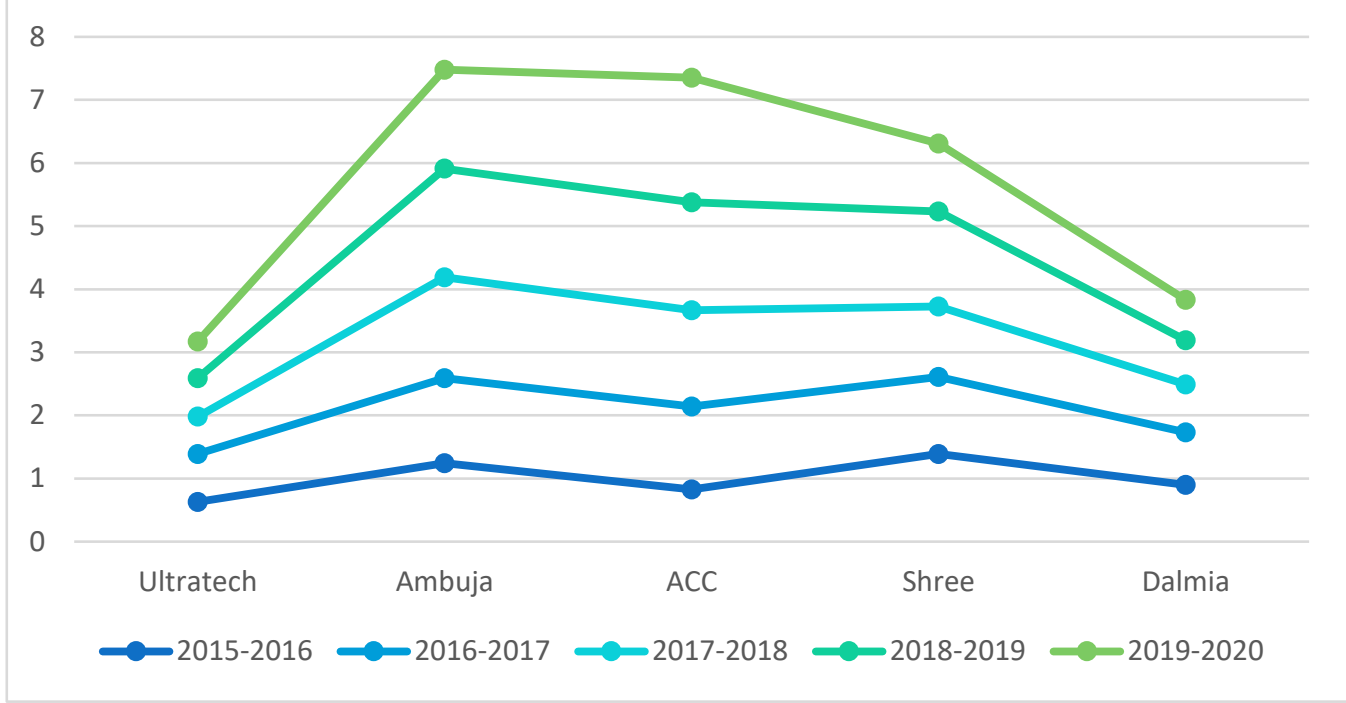

Figure 1. Current ratio of selected cement companies

The above table No.1 indicates the current ratio of the five selected cement company for the five year starting from 2015-16 and ending on 2019-2020.

In case of Ultratech cement ltd. Current ratio was $0.63 \%$ in the year 2015-16. Then in the year $2016-17$ it is increased by $0.13 \%$ reached up to $0.76 \%$ which is maximum ratio during the study of Ultratech cement company period of 5 years. Then in 2017-18 it was decrease up to $0.59 \%$ which was minimum ratio during the study of Ultratech cement company period of 5 years. In the year 2019-18 the ratio increased up to $0.61 \%$. In the year $2019-20$ it decreased by $0.03 \%$ and reached to $0.58 \%$. The average current ratio of Ultratech cement ltd is $0.634 \%$ during the study period of 5 years.

In the second case of Ambuja cement ltd. Current ratio was 1.24\% in the year 2015-16 which is minimum ratio during the study of Ambuja cement company period of 5 years. Then in the year 2016-17, 2017-18 and 2018-19 current ratio was continuously increase up to $1.35 \%, 1.60 \%$ and $1.72 \%$. In the year $2019-20$ ratio is $1.57 \%$ which is decline by $0.15 \%$ compare to year 2018-19. In the year 2018-19 ratio was $1.72 \%$ which is maximum ratio of Ambuja Cement Company during the study period of 5 years. The average current ratio of Ambuja cement ltd. Is $1.50 \%$ during the study period of 5 years.

In the case of ACC cement ltd. Current ratio was $0.83 \%$ in the year 2015-16 which is maximum ratio during the study of ACC cement company period 5 years. Then in the year 2016-17, 201718 and 2018-19 current ratio was continuously increase up to $1.31 \%, 1.53 \%$ and $1.71 \%$. In the year $2019-20$ current ratio is once again increase by $0.29 \%$ and stood up at $1.97 \%$ which is highest ratio of ACC Cement Company during the study period of 5 year. The average current ratio of ACC cement ltd. Is $1.47 \%$ during the study period of 5 years.

In the case of Sheer cement ltd. Current ratio was 1.39\% in the year 2015-16. Then ratio was respectively decreased to $1.22 \%$ and $1.12 \%$ in the year 2016-17 and 2017-18. In the year 201819 current ratio was reached to $1.50 \%$ which is the highest ratio of Shree Cement Company during the study period of 5 years. After year 2018-19 the current ratio was decrease $1.08 \%$ in the year 2019-20 which is minimum ratio during the study of Shree cement company period of 5 year. The average current ratio during the study period of 5 years of Shree cement ltd is $1.262 \%$. 
In the case of Dalmia cement ltd. Current ratio in the year 2015-16 was $0.90 \%$ which is maximum ratio during the study of Dalmia cement company period of 5 years. Then in the year 2016-17, 2017-18 and 2018-19 it was continuously decrease $0.83 \%, 0.76 \%$ and $0.70 \%$ respectively. In the year 2019-20 ratio was once again decrease up to $0.64 \%$, which is minimum ratio during the study of Dalmia cement company period of 5 years of Dalmia Cement Company. The average current ratio of Dalmia cement company was $0.77 \%$ during the study period of 5 years.

In the above table we can see that and analyzed that the highest or maximum current ratio was $1.97 \%$ in the year 2019-20 of ACC cement company and minimum current ratio was $0.59 \%$ of Ultratech cement company during the study of 5 selected companies and during the study period of 5 years.

\section{Hypothesis testing}

Ho: There is no significant difference in current ratio of selected cement companies during the Study period.

$>$ H1: There is significant difference in current ratio of selected cement companies during the Study period.

Table 2. ANOVA

\begin{tabular}{|c|c|c|c|c|c|c|}
\hline Source of Variation & SS & df & MS & F & P-value & F crit \\
\hline Between Groups & 3.226976 & 4 & 0.806744 & 14.78311222 & 9.0109406 & 2.866081402 \\
\hline Within Groups & 1.09144 & 20 & 0.054572 & & & \\
\hline Total & 4.318416 & 24 & & & & \\
\hline
\end{tabular}

The above ANOVA table shows that the calculated value $\mathrm{F}$ is 14.78311222 is more than the table value of 2.866081402 at the $5 \%$ level of significance and we accepted alternative hypothesis and reject null hypothesis. Hence, we conclude that there is significance difference in the current ratio of selected cement companies.

\section{Quick Ratio}

$>$ Formula:

\section{Quick ratio $=$ Current assets - Inventory \\ Current liabilities}

It is an indication of a firm's short-term liquidity situation and assesses the capacity of a corporation to satisfy its short-term obligations using the assets that are most readily available to it. Essentially, the quick ratio assesses a company's ability to fulfill its present creditors without having to liquidate goods or borrow extra funds. The quick ratio is believed to be a more conservative assessment than the current ratio, which incorporates all current assets as a gauge of their ability to pay for future obligations. It is believed that a larger ratio indicates more liquidity and financial health whereas a lower ratio indicates greater likelihood of a corporation experiencing financial difficulties in repaying its obligations. The quick ratio is a ratio that compares the dollar amount of liquid assets a firm has accessible to the dollar amount of current obligations that the company has. A company's current assets are those assets that may be quickly turned into cash with minimum influence on the price obtained in the open market, while current liabilities are those debts or obligations that must be paid to creditors within one year of the date of the asset's acquisition.

Table 3. Quick ratio of selected cement companies

\begin{tabular}{|c|c|c|c|c|c|}
\hline Year & Ultratech & Ambuja & ACC & Shree & Dalmia \\
61
\end{tabular}

Copyright $\odot$ 2021, Journal of Asian Multicultural Research for Economy and Management Study, Under the license CC BY-SA 4.0 


\begin{tabular}{|c|c|c|c|c|c|}
\hline $2015-2016$ & 0.58 & 0.99 & 0.57 & 1.02 & 0.64 \\
\hline $2016-2017$ & 0.61 & 1.11 & 1.06 & 0.92 & 0.57 \\
\hline $2017-2018$ & 0.59 & 1.30 & 1.23 & 0.92 & 0.55 \\
\hline $2018-2019$ & 0.63 & 1.52 & 1.50 & 1.15 & 0.47 \\
\hline $2019-2020$ & 0.60 & 1.31 & 1.81 & 0.87 & 0.45 \\
\hline MAX & 0.63 & 1.52 & 1.81 & 1.15 & 0.64 \\
\hline MIN & 0.58 & 0.99 & 0.57 & 0.87 & 0.45 \\
\hline AVERAGE & 0.602 & 1.246 & 1.234 & 0.976 & 0.536 \\
\hline
\end{tabular}

Source:

(https://www.google.com/URL?www.moneycontrol.com\%2F\&usg=AOvVaw2xmi4F6cHBL _upj3X)

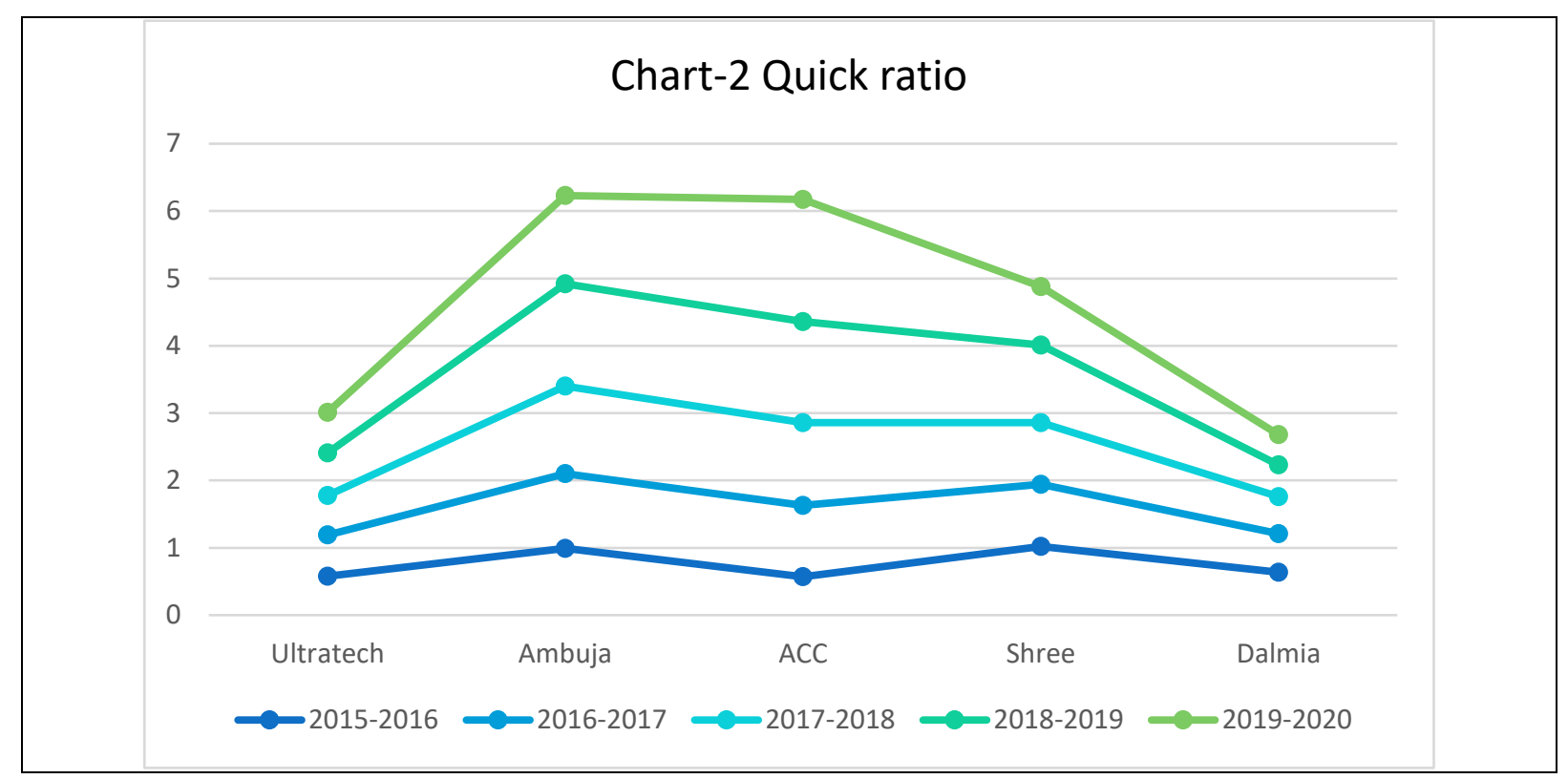

Figure 2. Quick ratio of selected cement companies

The above table.3 indicates the Quick ratio of the five selected cement company for the five year starting from 2015-16 and ending on 2019-2020.

In case of Ultratech cement ltd. Quick ratio was $0.58 \%$ in the year 2015-16 which is minimum quick ratio during the study of Ultratech cement company period of 5 years. Then in year 201617 and $2017-18$ quick ratio was $0.61 \%$ and $0.59 \%$ dereference between this two years is only $0.02 \%$. The maximum Quick ratio was $0.63 \%$ in the year $2018-19$ during the study of Ultratech cement company period of 5 years. In the year $2019-20$ the ratio was $0.63 \%$. The average Quick ratio of Ultratech cement ltd is $0.602 \%$ during the study period of 5 years.

In second case of Ambuja cement ltd. Quick ratio was 0.99\% in the year 2015-16 which is minimum quick ratio during the study of Ambuja cement company period of 5 years. Then in year 2016-17, 2017-18 and 2018-19 Quick ratio was continuously increased by $0.12 \%, 0.19 \%$ and $0.22 \%$ which is $1.11 \%, 1.30 \%$ and $1.52 \%$ as compare to previous year. After year 201819 ratio was decreased by $0.21 \%$ which is $1.31 \%$. The maximum Quick ratio was $1.52 \%$ in the year 2018-19 during the study of Ambuja cement company period of 5 years. The average Quick ratio of Ambuja cement ltd is $1.246 \%$ during the study period of 5 years.

In the case of ACC cement ltd. Quick ratio was $0.57 \%$ in the year 2015-16 which is minimum quick ratio during the study of ACC cement company period of 5 years. Then in year 2016-17, 2017-18, 2018-19 and 2019-20 Quick ratio was continuously increased by $0.49 \%, 0.17 \%$,

Copyright $\odot$ 2021, Journal of Asian Multicultural Research for Economy and Management Study, 
$0.27 \%$ and $0.31 \%$ which is $1.06 \%, 1.23 \%, 1.50 \%$ and $1.81 \%$ as compared to previous year. The maximum Quick ratio was $1.81 \%$ in the year 2019-20 during the study of ACC cement company period of 5 years. The average Quick ratio of ACC cement ltd is $1.234 \%$ during the study period of 5 years.

In the case of Shree cement ltd. Quick ratio was $1.02 \%$ in the year 2015-16. Then in year 201617 and 2017-18 there is no change in Quick ratio which is continue for two years is 0.92. After year 2018-19 ratio was increased by $023 \%$ which is $1.15 \%$ which is maximum Quick ratio during the study of Shree cement company period of 5 years. In the year the quick ratio is decline to $0.87 \%$ in the year 2019-20. The average Quick ratio of Shree cement ltd is $0.976 \%$ during the study period of 5 years.

In the case of Dalmia cement ltd. Quick ratio was $0.64 \%$ in the year 2015-16 which is maximum quick ratio during the study of Dalmia cement company period of 5 years. Then in year 2016$17,2017-18,2018-19$ and 2019-20 Quick ratio was continuously decline to $0.57 \%, 0.55 \%$, $0.47 \%$ and $0.45 \%$. The minimum Quick ratio was $0.45 \%$ in the year $2019-20$ during the study of Dalmia cement company period of 5 years. The average Quick ratio of Dalmia cement ltd is $0.536 \%$ during the study period of 5 years.

In the above table we can see that and analyzed that the highest or maximum Quick ratio was $1.81 \%$ in the year 2019-20 of Shree cement company and minimum Quick ratio was $0.45 \%$ of Dalmia cement company compare to other companies during the study period of 5 years

\section{Hypothesis Testing}

Ho: There is no significant difference in Quick ratio of selected cement companies during the Study period.

H1: There is significant difference in Quick ratio of selected cement companies during the Study period.

Table 4. ANOVA

\begin{tabular}{|c|c|c|c|c|c|c|}
\hline Source of Variation & SS & df & MS & F & P-value & F crit \\
\hline Between Groups & 2.282904 & 4 & 0.570726 & 10.23760494 & 0.000111705 & 2.866081402 \\
\hline Within Groups & 1.11496 & 20 & 0.055748 & & & \\
\hline Total & 3.397864 & 24 & & & & \\
\hline
\end{tabular}

The above ANOVA table shows that the calculated value F 10.2376 is more than the table value of 2.866081402 at the $5 \%$ level of significance. So that we conclude that accepted alternative hypothesis and reject null hypothesis. Hence, we conclude that there is significance difference in the Quick ratio of selected cement companies.

With its current or short-term assets, a company's capacity to pay current or short-term obligations is measured by the current or short-term ratio. A debt-to-equity ratio less than one implies that the company's obligations are due within a year. During a five-year period, the research demonstrates the ups and downs in the ratios of chosen cement businesses. It illustrates that the present ratio has been fluctuating between 2015-16 and 2019-20, indicating a mix tendency. When compared to other chosen cement businesses, Ambuja cement ltd. had a higher current ratio of 1.496 percent, ACC cement ltd. had a higher current ratio of 1.47 percent, and Shree cement ltd. had a higher current ratio of 1.262 percent. Which indicates that the ratio was negative, indicating that they are taking on too much debt or that their cash position is being drained, both of which might suggest a potential solvency risk if the situation worsens. Ultratech cement ltd. had a lower current ratio when compared to the other chosen cement businesses, with 0.634 percent and 0.766 percent, respectively, of Ultratech cement ltd. 
Positive results in the ratio might suggest improved collection, quicker inventory turnover, or that the firm has been successful in paying down debt.

Essentially, the quick ratio assesses a company's ability to fulfill its present creditors without having to liquidate goods or borrow extra funds. The research reveals the fluctuations in the ratios of chosen cement businesses during a five-year period, as well as the reasons behind these fluctuations. It reveals that the quick ratio has been fluctuating between 2015-16 and 2019-20, indicating a mix tendency. Ambuja cement ltd. and ACC cement ltd. both had higher fast ratios, with 1.246 percent and 1.234 percent, respectively. This demonstrates how well a firm's liquidity and financial health are doing, as well as how well the company is prepared with precisely enough assets to be promptly liquidated in order to pay off its present creditors as compared to other chosen cement companies. Shree cement ltd., Ultratech cement ltd., and Dalmia cement ltd. all had lower fast ratios than the industry average of 0.976 percent, 0.602 percent, and 0.536 percent, respectively. When compared to other chosen cement businesses, this implies that the companies have difficulty paying their obligations and may not be able to completely pay off their present commitments in the immediate term.

\section{Conclusion}

This research contributes to the understanding of the strengths and weaknesses of the cement industry in India. It is hoped that this research would help to increase understanding, especially in regards to different statistical tools and procedures, as well as statistical tests in general. In addition, the general public will have the opportunity to learn about the actual state of working capital management in the chosen cement businesses. To summarize the findings of the research, it can be said that the use of the aforementioned methods will unquestionably assist the chosen organizations in improving their overall performance in the management of working capital.

\section{References}

Abdulkareem, A. M. (2020). Financial Performance of Indian Pharmaceutical Companies: Analysis of Leverage and Cost of Capital. Journal of Advanced Research in Economics and Administrative Sciences, 1(1), 13-22.

Abdulkareem, A. M., \& Meghanathi, P. D. (2020). The Impact of Leverage on Earnings Per Share: A Study of Selected Petroleum Companies in India. Journal La Bisecoman, 1(2), 25-36.

Arunkumar, O. N., \& Ramanan, T. R. (2013). Working capital management and profitability: A sensitivity analysis. International Journal of Research and Development, 2(1), 5258.

Ganesamoorthy, L., \& Rajavathana, R. (2013). Management of working capital components among select automobile companies in India. Asian Journal of Management, 4(4), 301-307.

Hoque, A., Mia, A., \& Anwar, R. (2015). Working capital management and profitability: A study on cement industry in Bangladesh. Research Journal of Finance and Accounting, 6(7), 18-28.

Kieschnick, R., Laplante, M., \& Moussawi, R. (2013). Working capital management and shareholders' wealth. Review of Finance, 17(5), 1827-1852.

Oladipupo, A. O., \& Okafor, C. A. (2013). Relative contribution of working capital management to corporate profitability and dividend payout ratio: Evidence from Nigeria. International Journal of Business and Finance Research, 3(2), 11-20.

Copyright ( 12021 , Journal of Asian Multicultural Research for Economy and Management Study,

Under the license CC BY-SA 4.0 
Paul, P., \& Mitra, P. (2018). Analysis of the effect of working capital management on profitability of the firm: Evidence from Indian steel industry. Asia-Pacific Journal of Management Research and Innovation, 14(1-2), 32-38. 